\title{
MYH9-Related Platelet Disorders
}

\author{
Karina Althaus, M.D., ${ }^{1}$ and Andreas Greinacher, M.D. ${ }^{1}$
}

\section{ABSTRACT}

Myosin heavy chain 9 (MYH9)-related platelet disorders belong to the group of inherited thrombocytopenias. The MYH9 gene encodes the nonmuscle myosin heavy chain IIA (NMMHC-IIA), a cytoskeletal contractile protein. Several mutations in the MYH9 gene lead to premature release of platelets from the bone marrow, macrothrombocytopenia, and cytoplasmic inclusion bodies within leukocytes. Four overlapping syndromes, known as May-Hegglin anomaly, Epstein syndrome, Fechtner syndrome, and Sebastian platelet syndrome, describe different clinical manifestations of MYH9 gene mutations. Macrothrombocytopenia is present in all affected individuals, whereas only some develop additional clinical manifestations such as renal failure, hearing loss, and presenile cataracts. The bleeding tendency is usually moderate, with menorrhagia and easy bruising being most frequent. The biggest risk for the individual is inappropriate treatment due to misdiagnosis of chronic autoimmune thrombocytopenia. To date, 31 mutations of the MYH9 gene leading to macrothrombocytopenia have been identified, of which the upstream mutations up to amino acid $\sim 1400$ are more likely associated with syndromic manifestations than the downstream mutations. This review provides a short history of MYH9-related disorders, summarizes the clinical and laboratory characteristics, describes a diagnostic algorithm, presents recent results of animal models, and discusses aspects of therapeutic management.

KEYWORDS: MYH9 gene, nonmuscle myosin IIA, May-Hegglin anomaly, Epstein syndrome, Fechtner syndrome, Sebastian platelet syndrome, macrothrombocytopenia

The correct diagnosis of hereditary chronic thrombocytopenias is important for planning appropriate treatment of individuals with these conditions and reducing their risk of unnecessary therapy for an incorrect diagnosis, such as chronic (auto)immune thrombocytopenia (ITP). Several of the conditions associated with chronic thrombocytopenia are referred to as "macrothrombocytopenias" as platelet size is greatly increased in these disorders (Fig. 1).

Hereditary macrothrombocytopenias are often autosomal dominant although some have an X-linked or recessive inheritance. ${ }^{1}$ These conditions can present

${ }^{1}$ Institut für Immunologie und Transfusionsmedizin, Ernst-MoritzArndt-Universität Greifswald, Greifswald, Germany.

Address for correspondence and reprint requests: Prof. Dr. Andreas Greinacher, Institut für Immunologie und Transfusionsmedizin, Ernst-Moritz-Arndt Universität Greifswald, Sauerbruchstraße, D 17475 Greifswald, Germany (e-mail: greinach@uni-greifswald.de).

Diagnostic Evaluation of Platelet Function Disorders; Guest as isolated platelet count reductions or as part of more complex clinical syndromes. Individuals with hereditary macrothrombocytopenia and minor bleeding symptoms are very often misdiagnosed as having the more common disorder, chronic ITP, which can place them at higher risk for receiving inappropriate clinical treatments. In our own series of 39 affected families, 6 affected individuals had undergone (ineffective) splenectomy, and nearly all had received immunosuppressive treatment with corticosteroids, azathioprine, or intravenous $\operatorname{IgG}$, some of them for years.
Editors, Catherine P.M. Hayward, M.D., Ph.D., F.R.C.P.(C.), and Emmanuel J. Favaloro, Ph.D., M.A.I.M.S.

Semin Thromb Hemost 2009;35:189-203. Copyright (C) 2009 by Thieme Medical Publishers, Inc., 333 Seventh Avenue, New York, NY 10001, USA. Tel: +1(212) 584-4662.

DOI 10.1055/s-0029-1220327. ISSN 0094-6176. 




$[+L]$

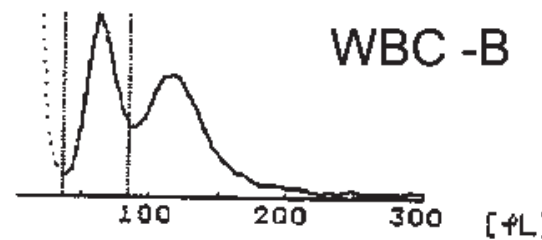

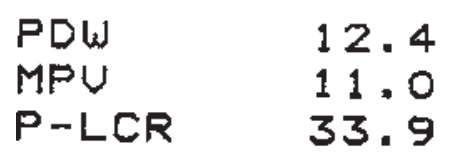

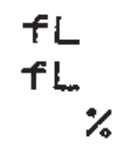

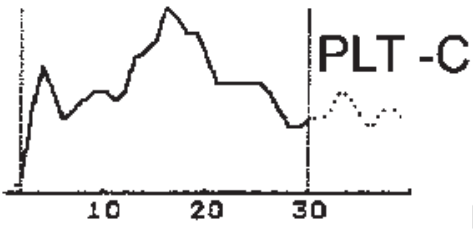

[fL]

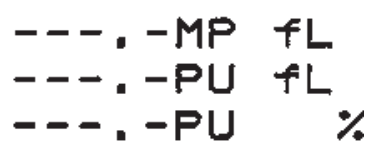

WBC -D

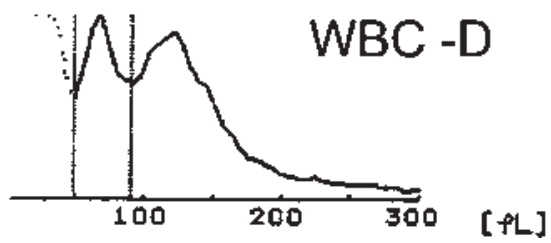

Figure 1 Histogram of $(A)$ normal platelets (PLT) shows a semilogarithmic curve, and (B) the line of the respective leukocyte histogram starts close to baseline. In contrast, the histograms of an individual with macrothrombocytopenia show (C) a typical broad distribution and indeterminate, but greatly increased, MPV, with (D) the line of the respective leukocyte (WBC) histogram shifted upward due to the peak of large platelets (dotted line), which are erroneously gated as leukocytes. PDW, platelet distribution width; MPV, mean platelet volume; P-LCR, platelet-large cell ratio; fl, femto liter.

After characterization of genetic mutations in the myosin heavy chain 9 (MYH9) gene that lead to the formation of giant platelets due to alterations of the protein nonmuscle myosin IIA (NMM-IIA), ${ }^{2-7}$ there is increasingly recognition that at least half of all macrothrombocytopenias with defined underlying defects are caused by MYH9 mutations. ${ }^{8}$ In this review, we address the history of this group of macrothrombocytopenias, provide a brief overview on their clinical presentation and laboratory diagnosis, summarize the genetic mutations and the known biological functions of NMM-IIA, and provide data on potential mutation-function relationships. Finally, we summarize treatment recommendations based on our experience of managing individuals with dominantly inherited macrothrombocytopenias in various clinical situations.

\section{HISTORY OF MYH9-RELATED DISORDERS}

In 1909, May described a family in which several members had enlarged platelets but minor if any bleeding symptoms. ${ }^{9}$ In 1945 , Hegglin ${ }^{10}$ found Döhle bodylike inclusions within the leukocytes of affected individuals with a dominantly-inherited giant platelet disorder. This led to the term May-Hegglin anomaly (MHA) to describe the triad of thrombocytopenia, giant platelets, and leukocyte inclusion bodies. These inclusion bodies are spindle shaped and appear bright blue in standard blood films. ${ }^{11}$

In 1972, Epstein et $\mathrm{al}^{12}$ described Epstein syndrome (EPS) as the first macrothrombocytopenic syndrome characterized by giant platelets, associated with deafness and nephritis; however, in contrast with MHA, leukocyte inclusion bodies were absent. About a decade later, in 1985, Peterson et $\mathrm{al}^{13}$ characterized another dominantly inherited macrothrombocytopenic syndrome, characterized by interstitial nephritis, cataract, deafness (i.e., a syndrome complex resembling Alport syndrome), and leukocyte inclusions. These inclusion bodies were much smaller than those observed in the MHA and typically round rather than spindle shaped. These authors called the disorder Fechtner syndrome (FS). In 1990, Greinacher et $\mathrm{a}^{14}$ described a milder variant macrothrombocytopenia, Sebastian platelet syndrome (SPS), with small inclusion bodies in leukocytes. At the time of the initial report, the affected SPS family members did not show cataracts, renal impairment, or high-tone neurosensorial deafness. However, when this family was reevaluated 18 years later, several affected individuals were recognized to have developed cataracts at a young age (45 to 50 years), and all affected family members that were $>50$ years of age had developed high-tone hearing impairment.

In 1999, the inheritance of these giant platelet disorders was linked to a $5.5-\mathrm{Mb}$ region on the short arm of chromosome 22q. ${ }^{2,15}$ Soon afterwards, two groups $^{4,16}$ characterized mutations in the MYH9 gene as the underlying cause of these macrothrombocytopenias. The syndromes MHA, EPS, FS, and SPS are now recognized to be related disorders, caused by mutations in the MYH9 gene, with phenotypic differences related to the presence or absence of the additional features of cataracts, nephritis, and sensorineural hearing loss (Table 1). It has therefore been suggested that these disorders should be referred to as MYH9-related macrothrombocytopenias. ${ }^{4,17,18}$ 
Table 1 Clinical and Laboratory Findings in MYH9Related Disease

\begin{tabular}{lllll}
\hline & MHA & FS & EPS & SPS \\
\hline Macrothrombocytopenia & + & + & + & + \\
Inclusion bodies & + & + & - & + \\
Hearing loss & - & + & + & - \\
Nephritis & - & + & + & - \\
Cataract & - & + & - & - \\
\hline
\end{tabular}

\section{CLINICAL PRESENTATION OF MYH9 DISORDERS}

MYH9-related disorders present a spectrum of clinical features. Giant platelets are present in all affected individuals, with platelet numbers varying from $30,000 / \mu \mathrm{L}$ to $100,000 / \mu \mathrm{L}$. The associated clinical features can vary considerably between individuals, even among family members and others with the same mutation. The variable features include the degree of bleeding tendency, renal impairment, and the age of onset of cataracts and hearing loss. Petechiae are rarely seen compared with problems with bruising and hematomas. Although major bleeding episodes are rare, one fatal spontaneous intracranial bleeding has been reported in an individual with MYH9-related disease. ${ }^{19}$ Women with MYH9-related disorders often experience menorrhagia. In fact, the index cases in affected families are often women, who are noted to have macrothrombocytopenia when their irondeficiency anemia prompts a hematologic workup.
Figure 2 shows the pedigree of one of the families diagnosed in our laboratory, which exemplifies the typical clinical presentation of affected families. The 13-year-old girl (III-III) presented to a pediatrician, with menorrhagia and iron-deficiency anemia. Her father (40 years old; II-III), aunt (44 years old; II-II), cousin (19 years old; III-I), and grandfather (67 years old; I-I) were then diagnosed with the same disorder. Whereas the aunt had previously been identified as having thrombocytopenia (during evaluation of menorrhagia and iron-deficiency anemia), the thrombocytopenia was unrecognized in the father, grandfather, and cousin until our laboratory diagnosing MYH9-related disorder in the proband led to investigations of other family members. The aunt (II-II) was misdiagnosed as having ITP several years earlier and received treatment with several courses of intravenous immunoglobulin $G$ (IgG) and corticosteroids, without platelet count increases. Splenectomy had also been recommended, but this treatment was declined. Sensorineural hightone hearing impairment was detected, by audiograms, in many affected family members (the father, aunt, and grandfather), except for the younger individuals (13-year-old proband and her 19-year-old cousin).

\section{INCIDENCE OF MYH9 DISORDERS}

The prevalence of MYH9-related disorders is probably underestimated because of underreporting and frequent

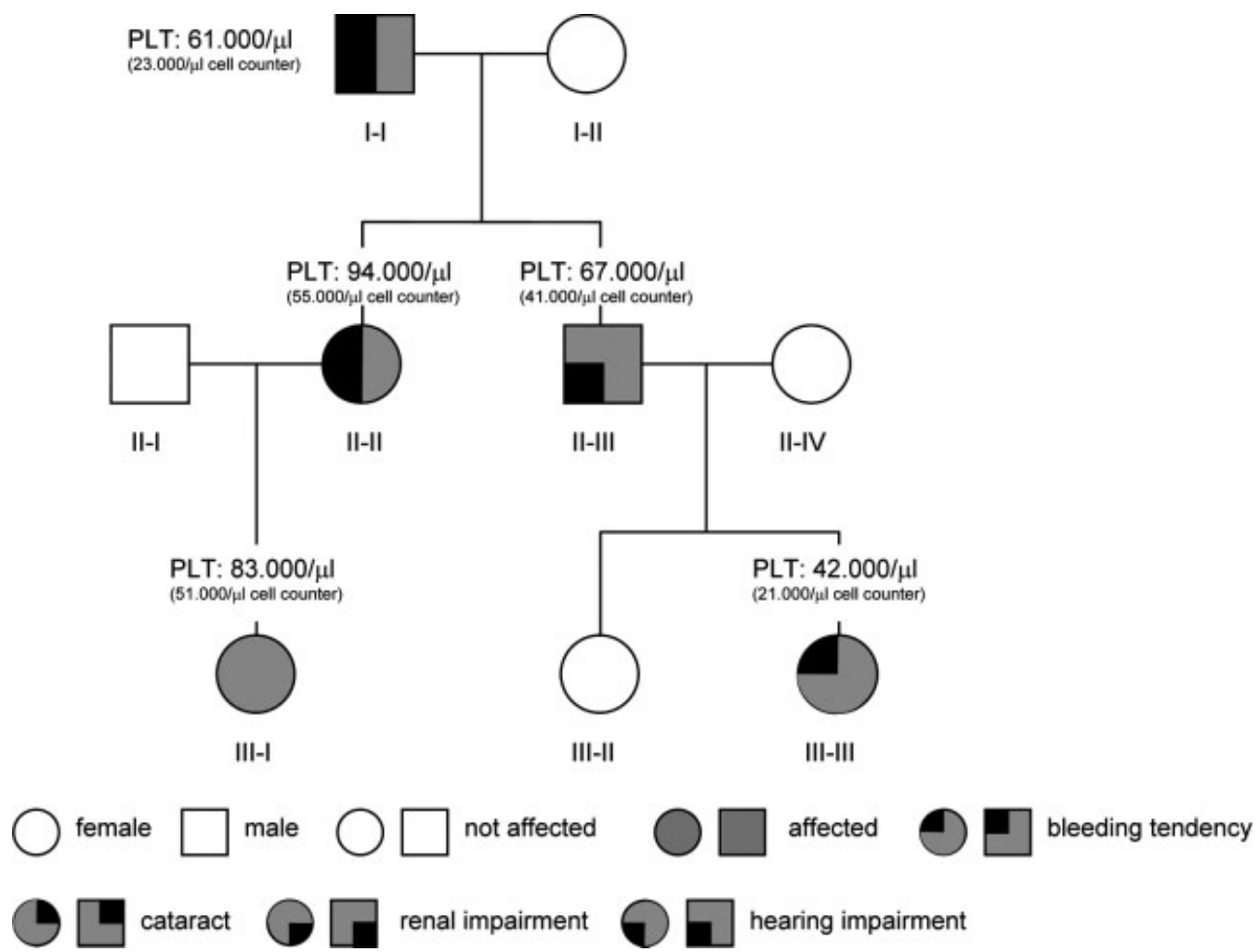

Figure 2 Pedigree of an affected family with macrothrombocytopenia. Individual III-III is the proband, her aunt (II-II) was misdiagnosed as having ITP, and the other family members were detected through family screening. PLT, platelets. 
misdiagnosis. In the literature, 101 unrelated families with MYH9 disorders have been described ${ }^{4-6,20-30}$ indicating a low prevalence (Table 2). However, we have identified, in the Greifswald region only, an additional five unrelated families with different MYH9 mutations (catchment area of $\sim 250,000$ habitants). The many different mutations in the 40 exons of the MYH9 gene identified in association with hereditary thrombocytopenia (see later) further suggest that MYH9-related disorders are not rare.

\section{DIAGNOSIS OF MYH9 DISORDERS}

A careful evaluation of platelet and granulocyte morphology is important for the laboratory diagnosis of
MYH9 disorders. All modern particle counters determine the mean platelet volume (MPV), and most machines also generate a histogram showing size distribution of platelets. An MYH9-related macrothrombocytopenia should be suspected in individuals that have large platelets, a high MPV, a broad platelet histogram, and a peak preceding the leukocyte histogram (Fig. 1). For the clinical management of individuals with an MYH9 disorder, it is important to be aware of the risk of obtaining an artifactually low platelet count by standard automatic particle counters as the large platelets are often counted as red blood cells or leukocytes. Thus, platelet and white blood cell enumeration should be performed manually, especially when the individual also has "leukocytosis."

Table 2 Mutations in MYH9-Related Thrombocytopenia and Reported Clinical Features s-6,20-30 $^{4}$

\begin{tabular}{|c|c|c|c|c|c|c|}
\hline \multirow[b]{2}{*}{ Exon } & \multirow[b]{2}{*}{ Mutation } & \multirow{2}{*}{$\begin{array}{l}\text { Number of } \\
\text { Affected Families } \\
\text { Reported }\end{array}$} & \multirow[b]{2}{*}{ Thrombocytopenia } & \multicolumn{3}{|c|}{$\begin{array}{l}\text { Number of Families with Additional Symp- } \\
\text { toms Beside Macrothrombocytopenia }\end{array}$} \\
\hline & & & & $\begin{array}{l}\text { Hearing } \\
\text { Impairment }\end{array}$ & $\begin{array}{l}\text { Renal } \\
\text { Impairment }\end{array}$ & Cataract \\
\hline 1 & N93K & 2 & Yes & 0 & 0 & 0 \\
\hline 1 & A95T & 1 & Yes & 0 & 0 & 0 \\
\hline 1 & S96L & 4 & Yes & 3 & 3 & 0 \\
\hline 10 & K371N & 1 & Yes & 0 & 0 & 0 \\
\hline 16 & $\mathrm{R} 702 \mathrm{C}$ & 7 & Yes & 7 & 7 & 3 \\
\hline 16 & $\mathrm{R} 702 \mathrm{H}$ & 4 & Yes & 4 & 4 & 1 \\
\hline 16 & $\mathrm{R} 705 \mathrm{H}$ & 1 & No & 1 & * & * \\
\hline 16 & Q706E & 1 & Yes & $*$ & * & * \\
\hline 16 & R718W & 1 & Yes & 1 & 1 & 1 \\
\hline 24 & E1066-A1072del & 1 & Yes & 0 & 0 & 1 \\
\hline 25 & V1092-R1162del & 1 & Yes & 0 & 1 & 0 \\
\hline 25 & D1114P & 1 & Yes & 0 & 1 & 0 \\
\hline 26 & T1155A & 1 & Yes & 1 & 1 & 1 \\
\hline 26 & T1155I & 5 & Yes & 0 & 0 & 0 \\
\hline 26 & $\mathrm{R} 1165 \mathrm{C}$ & 5 & Yes & 2 & 2 & 2 \\
\hline 26 & R1165L & 2 & Yes & 2 & 2 & 0 \\
\hline 26 & L1205-Q1207del & 1 & Yes & 0 & 0 & 0 \\
\hline 30 & R1400W & 1 & Yes & 0 & 1 & 0 \\
\hline 30 & D1424Y & 2 & Yes & 1 & 1 & 1 \\
\hline 30 & D1424N & 13 & Yes & 8 & 4 & 4 \\
\hline 30 & D1424H & 3 & Yes & 2 & 1 & 1 \\
\hline 30 & D1447V & 1 & Yes & * & * & * \\
\hline 31 & V1516L & 1 & Yes & * & 1 & 1 \\
\hline 37 & I1816V & 1 & Yes & 1 & 1 & 0 \\
\hline 38 & E1841K & 20 & Yes & 0 & 5 & 1 \\
\hline 40 & G1924fs & 1 & Yes & * & * & * \\
\hline 40 & D1925fs & 1 & Yes & 0 & 0 & 0 \\
\hline 40 & P1927fs & 1 & Yes & 0 & 0 & 0 \\
\hline 40 & R1933fs & 1 & Yes & 0 & 0 & 0 \\
\hline 40 & R1933X & 14 & Yes & 14 & 1 & 0 \\
\hline 40 & E1945 & 2 & Yes & 0 & 2 & 0 \\
\hline
\end{tabular}

${ }^{*}$ no data available; fs, frameshift; del deletion. 


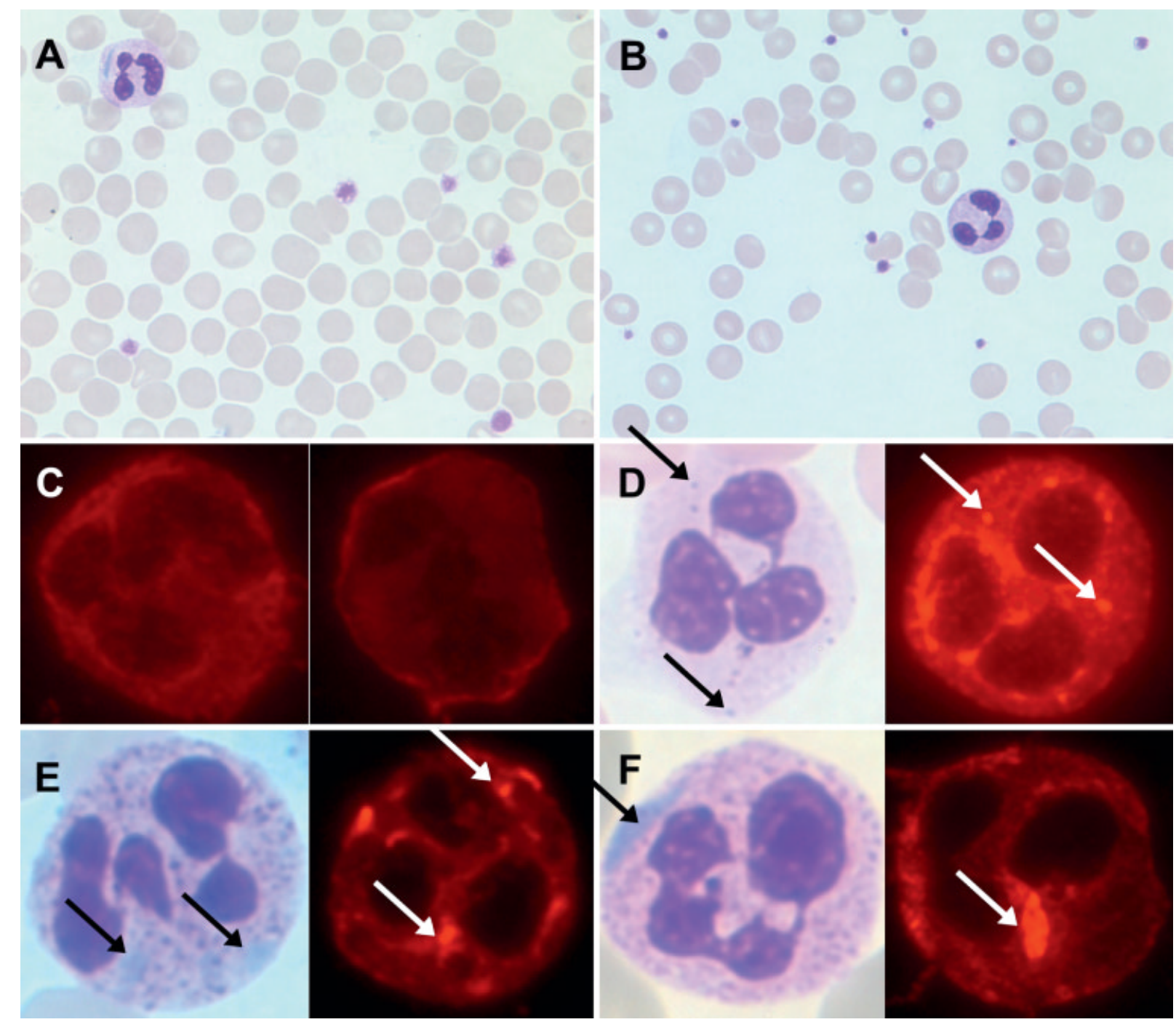

Figure 3 NMM-IIA in neutrophils stained with an anti-NMM-IIA monoclonal antibody (immunofluorescence) or MayGrünwald-Giemsa. (A) Blood smear of a individual with MYH9-related disease: enlarged platelets; (B) normal blood smear; (C) wild type, normal distribution of NMM-IIA; (D) mutation in exon 1: nearly normal distribution of NMM-IIA, just small punctuate clusters; (E) mutation in exon 30: multiple oval-shaped cytoplasmic spots; (F) mutation in exon 38: one large, intensely stained cluster. Arrows in figure point to typical cluster of NMMHC-IIA in neutrophils.

On peripheral blood, May-Grünwald-Giemsa stained smears, the giant platelets can be easily seen. Especially when a lower magnification is used, it becomes obvious that most, if not all, platelets are nearly as big as red blood cells (Fig. 3A). Often, the easiest diagnostic approach is to perform routine blood counts in firstdegree relatives. If a second family member shows the same features, neutrophils should be carefully assessed. The abnormal distribution of NMM-IIA within the neutrophils is also a characteristic feature of MYH9 disorders. Whereas the large spindle-shaped inclusion bodies characteristic for the MHA are very prominent (Fig. 3F), the smaller leukocyte inclusion bodies of the other syndromes are more challenging to detect (Fig. 3D, E). These inclusion bodies are best visualized when blood smears are stained within 4 hours after blood taking ${ }^{14}$ using the classic May-Grünwald-Giemsa stain rather than the more commonly used Wright's stain. The current "gold standard" for demonstrating MYH9 leukocyte inclusion bodies is the detection, by immunostaining, of NMM-IIa clusters (see later).

Platelet aggregometry and platelet function studies using the PFA-100 (Siemens Healthcare Diagnostics, Marburg, Germany) do not show major defects in MYH9 disorders. Because of the altered composition of the platelet cytoskeleton, the shape change in the aggregation curve is typically absent ${ }^{31}$ (Fig. 4). Although this is an additional typical feature of MYH9 disorders, an absent shape change may also be found in other platelet disorders, as it depends on complex intracellular signaling. ${ }^{32}$

A bone marrow examination is not required for diagnosing MYH9 disorders. If performed, the marrow 
A
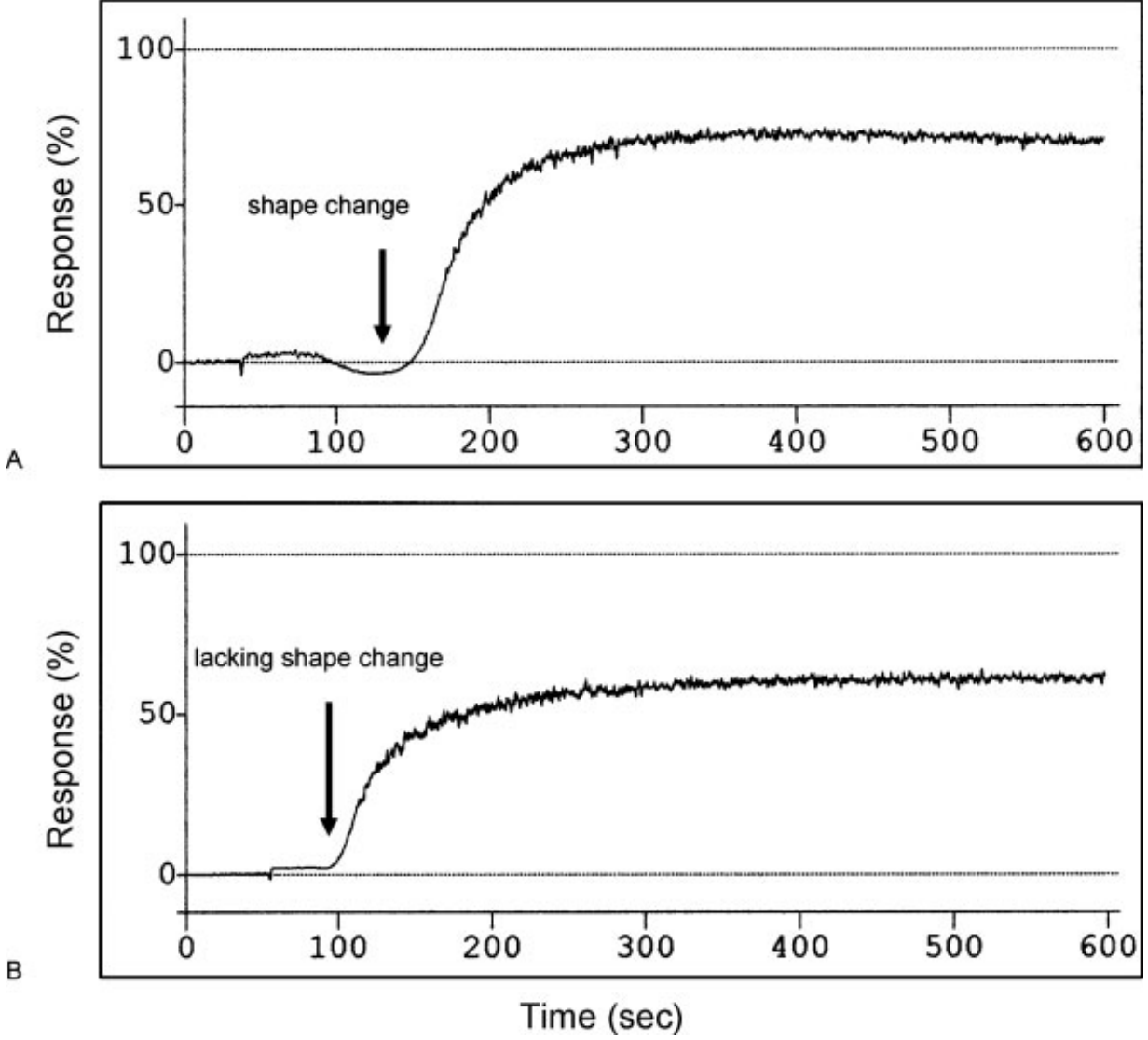

Figure 4 (A) Normal-sized platelets: normal response to collagen with typical shape change. (B) Giant platelets: slight impaired response to collagen and absent shape change, which is a typical finding in MYH9 disorders.

typically shows normal or moderately elevated numbers of megakaryocytes with normal morphology. This contributes to the frequent misdiagnosis of autoimmune thrombocytopenia.

Diagnostic workup of MYH9 disorders should also include exclusion of iron-deficiency anemia (especially in women at childbearing age) and an audiogram, ophthalmologic screening for cataracts, and renal function assessment (creatinine clearance and proteinuria). In our own practice, we recommend assessment of the iron status once per year and also repeat renal function tests every 5 years until the age of $\sim 40$ years and then every 2 to 3 years thereafter, as early detection of renal impairment has certain treatment implications (as outlined later).

\section{Hypothesis on the Mechanism of Bleeding with MYH9-Related Disorders}

The most important reason for bleeding is the reduced clot stability due to impaired clot retraction by platelets with a disturbed cytoskeleton. ${ }^{33}$ This is aggravated in case of iron-deficiency anemia. In general, larger particles, such as red blood cells, flow in the middle of the microcirculatory bloodstream, whereas the smaller-sized platelets flow near the vessel wall, thus enhancing their potential for subendothelial interaction. However, when there are giant platelets, as in MYH9-related disorders, platelets localize more within the middle of the flowing bloodstream because of their size and are less available for subendothelial interaction (Fig. 5). In addition, this is aggravated by anemia, which also reduces the red blood cell contributions of arachidonic acid and adenosine diphosphate for activating platelets. ${ }^{34}$

\section{OTHER MACROTHROMBOCYTOPENIAS TO BE CONSIDERED IN THE DIFFERENTIAL DIAGNOSIS OF MYH9 DISORDERS}

Chronic autoimmune thrombocytopenia (chronic ITP) is the most important condition to distinguish from MYH9 disorders because of potential therapeutic consequences. There are several characteristics that may help to differentiate these entities. First, and potentially the easiest to assess, is to evaluate platelet size using the blood film, platelet size histogram, and (calculated) MPV. In ITP, usually less than $10 \%$ of platelets are "giant" platelets with a size approaching that of red blood cells, unless platelets are evaluated during the early recovery phase of acute severe ITP after treatment with high-dose intravenous $\mathrm{IgG}$ (unpublished observations of the authors). Second, a determination of platelet counts of first-degree relatives 

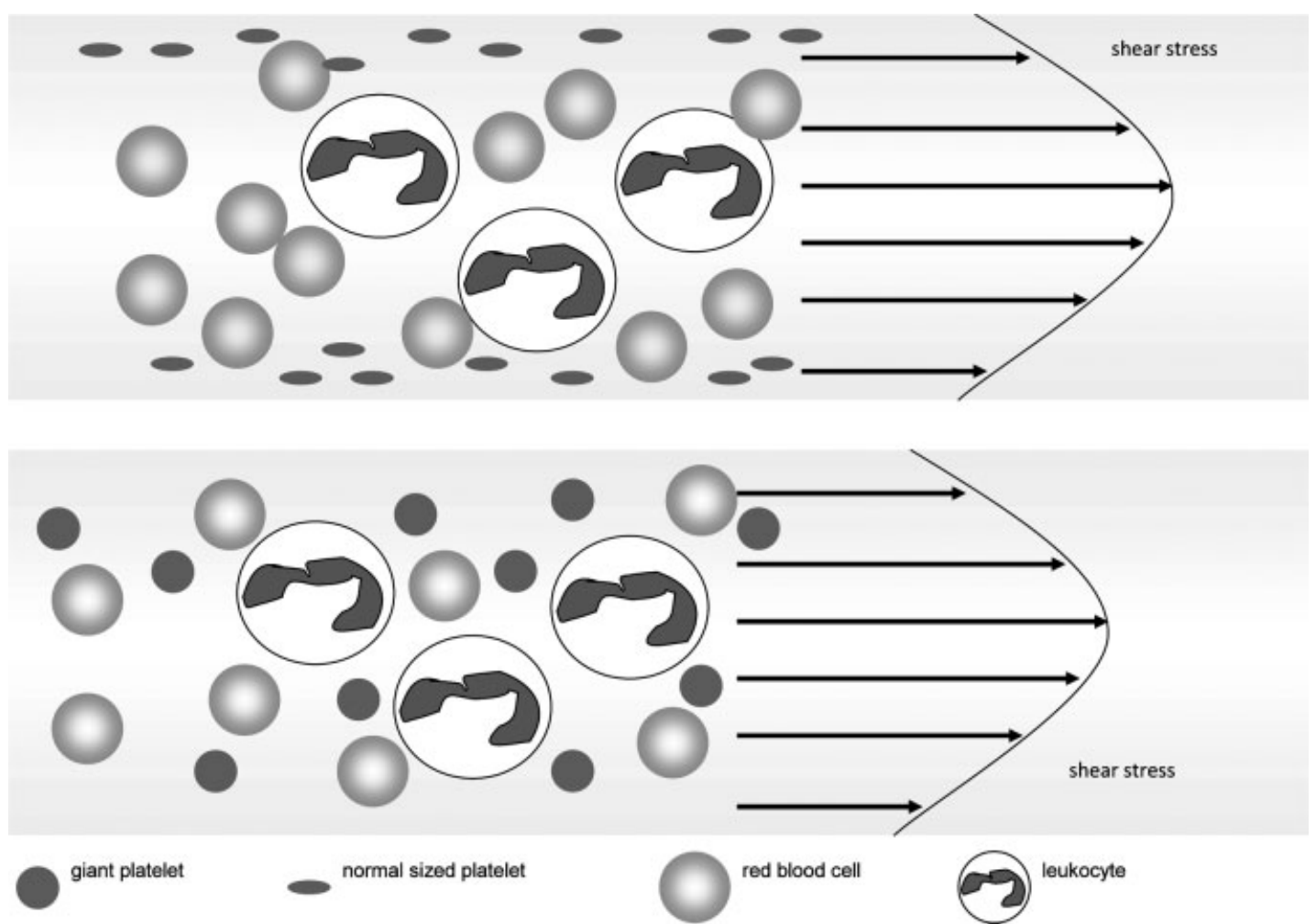

Figure 5 In the circulation, normal-sized platelets flow close to the vessel wall, whereas giant platelets tend to flow in the middle of the blood vessel. Reduced red cell numbers (e.g., due to iron deficiency) also decrease the numbers of platelets that flow near the vessel wall. Although flow rates are greatest in the middle of the vessels, the highest shear stresses (which maximize VWF-mediated adhesion of platelets to injured subendothelium) are found at the vessel wall.

(which is also relatively easy to perform) can help determine if the thrombocytopenia is hereditary. If another family member also exhibits thrombocytopenia, the diagnosis of ITP is unlikely. As individuals with MYH9 disorders usually show only minor bleeding, it is warranted to request a complete blood count on all firstdegree relatives, regardless of their bleeding history. Third, individuals with MYH9 disorders do not respond to intravenous $\operatorname{IgG}$ with a major increase in platelet counts, although transient mild increases in platelet counts (e.g., by 20,000 to $30,000 / \mu \mathrm{L}$ ) can follow a course of high-dose corticosteroids. Fourth, platelet glycoprotein-specific autoantibodies are not present in individuals with MYH9 disorders but are detectable in $\sim 50 \%$ of individuals with chronic ITP. ${ }^{35}$ However, it is not helpful to measure platelet-associated $\operatorname{IgG}$ levels as the giant platelets of MYH9 disorders have increased non-glycoprotein-specific IgG bound to their larger platelet membranes. Nonetheless, acute ITP, complicating MYH9 thrombocytopenia, has been reported in a young woman who first became clinically symptomatic after developing postinfection ITP. ${ }^{36}$ Although this individual responded rapidly to corticosteroids, her platelet counts never increased to $>40,000 / \mu \mathrm{L}$.

Bernard-Soulier syndrome (BSS) is an autosomal recessive giant platelet disorder that is usually caused by reduced or absent expression of the glycoprotein (GP) Ib-IX-V receptor complex. ${ }^{37,38}$ Platelets in BSS are as large as in the MYH9 disorders and appear similar to MYH9 platelets by light microscopy and electron microscopy ultrastructural analysis. Aggregation studies can help to distinguish a MYH9 disorder from the rare, dominant Bolzano type of BSS, in which the GP IbIX-V complex is expressed but functionally impaired. ${ }^{39}$ In BSS, there is typically absent agglutination with ristocetin, despite aggregation responses to other agonists. The diagnosis of BSS is typically confirmed by quantitative analysis of GP Ib-IX complex expression on the platelets or genetic testing.

It can be difficult to distinguish an MYH9 disorder from a heterozygous carrier of the BSS mutations, as platelet agglutination with ristocetin is normal in BSS carriers. Carriers of BSS can have a moderately decreased platelet count (often 100,000 to $120,000 / \mu \mathrm{L}$ ) and somewhat enlarged platelets with only a few giant platelets. Carriers of BSS typically have asymptomatic thrombocytopenia that does not require treatment. An option to consider, to distinguish heterozygote BSS carriers from individuals with MYH9 disorders (without genetic testing), is to determine the ratio between GP Ib-IX and GP IIb-IIIa, which is characteristically reduced in BSS carriers but not in MYH9 thrombocytopenia. 
Paris-Trousseau syndrome/Jacobson syndrome is a disorder with large platelets that contain giant $\alpha$-granules. This syndrome is distinguished from MYH9 disorders by its features of mental retardation, facial and cardiac abnormalities, and its genetic cause, which is a heterozygous deletion of one part of chromosome $11 \mathrm{q} 23 .^{40,41}$

X-linked macrothrombocytopenia can be caused by a mutation in the GATA-1 gene Xp11-12, a transcription factor important for megakaryopoiesis and erythropoiesis. The disorder is associated with splenomegaly and red cell abnormalities (reticulocytosis and anemia) and thrombocytopenia with platelet function defects (decreased agglutination with ristocetin, weak aggregation with collagen). ${ }^{42,43}$

Gray platelet syndrome (GPS) is an autosomal recessive bleeding disorder associated with giant platelets containing empty $\alpha$-granules and moderate thrombocytopenia - the appearance of pale and gray platelets in the blood smear is an important diagnostic clue to distinguish this condition from MYH9 disorders. The genetic defect is unknown. ${ }^{44,45}$

\section{IMMUNOSTAINING OF NMM-IIA INCLUSION BODIES}

The NMM-IIA inclusion bodies in the leukocytes can be visualized using specific antibodies. ${ }^{6,21}$ According to the location of the mutation, clusters of NMM-IIA can be detected as oval-spindle-shaped, oval-shaped, or round inclusion bodies. Neutrophils with one or two large oval-spindle-shaped inclusion bodies are typically present in individuals with mutations in exons 38 and 40.
Smaller and round or slightly oval-shaped clusters are usually associated with mutations within exons 26 to 30 (Fig. 3), whereas speckled small punctate clusters are more often found in individuals with mutations in exon 1 and exon $37 .^{22}$

\section{MUTATION ANALYSIS}

Mutation analysis is not crucial for diagnosis of MYH9 disorders. Moreover, a full assessment requires screening of 40 exons, although exon 30 seems to be the site of many mutations. Genetic testing has been postulated to help assess the risk of development of high-tone hearing loss, cataracts, or renal impairment, although there is debate about the extent of mutation-phenotype correlations in MYH9 disorders.

\section{NMM-IIA PROTEIN AND ITS GENE MYH9}

\section{The NMM-IIA Protein}

Myosins are mechanoenzymes that play a fundamental role in cell motility. They are involved in cytokinesis, phagocytosis, cell motility, and maintenance of cell shape. Nonmuscle myosin class II is part of the myosin superfamily ${ }^{46}$ which consists of 18 myosin classes identified to date. Three isozymes of nonmuscle myosin II are present in humans: NMM-IIA, NMM-IIB, and NMM-IIC. Eosinophils express NMM-IIA and NMM-IIB, whereas platelets, lymphocytes, neutrophils. and monocytes express only NMM-IIA ${ }^{47}$ (Table 3 ). Studies of individuals with MYH9-related macrothrombocytopenia by Kunishima et al ${ }^{21}$ demonstrated (by immunofluorescent

Table 3 Expression of NMM-IIA, NMM-IIB, and NMM-IIC in Mouse Tissue ${ }^{47,49}$

\begin{tabular}{|c|c|c|c|}
\hline Mouse Tissue & II-A & II-B & II-C \\
\hline Embryonic liver foci & ++ & & \\
\hline Embryonic kidney & ++ & + & + \\
\hline Embryonic eye & ++ (lens epithelium) & + (retina) & + (lens and retina) \\
\hline Embryonic palate & ++ & & + \\
\hline Embryonic vessel endothelium & ++ & & \\
\hline Hair follicles & ++ & & + \\
\hline Cochlea & ++ & + & +++ \\
\hline Developing teeth & ++ & & + \\
\hline Lachrymal gland & ++ & & + \\
\hline $\begin{array}{l}\text { Embryonic and neonatal } \\
\text { central nervous system }\end{array}$ & & ++ & + \\
\hline Heart & & + & $+1-$ \\
\hline Embryonic cartilage & & & + \\
\hline Embryonic gut & ++ & + & + \\
\hline Platelet & ++ & & \\
\hline Neutrophil granulocytes & ++ & & \\
\hline Eosinophil granulocytes & + & + & \\
\hline Monocytes & ++ & & \\
\hline Lymphocytes & ++ & & \\
\hline
\end{tabular}


microscopy and immunoblotting) that while NMM-IIA is uniformly diminished, without evidence of aggregates, in the monocytes, large platelets, and $\mathrm{CD} 34^{+}$cells of affected individuals, their granulocytes contain NMMIIA in clusters. These observations suggest NMM-IIa has different blood cell type-specific functions.

NMM-IIA normally exists as a large hexamer, composed of two nonmuscle myosin heavy chains (NMMHC; MW $220 \mathrm{kDa}$ ) and 4 light chains (MLC; MW $16.5 \mathrm{kDa}$ ), with a total molecular mass of $453 \mathrm{kDa}$. It has a $\mathrm{N}$-terminal head (exon 1 to 18 ), a neck (exon 19), and a C-terminal tail (exon 20 to 40) ${ }^{48-50}$ (Fig. 6). The $\mathrm{N}$-terminal head interacts with actin and exposes the ATP-binding side. The neck includes the IQ-motif, which is an important binding site for the MLCs. The MLC is responsible for inducing the actomyosin contractile response. By phosphorylation of MLC, myosin becomes activated and can interact with actin filaments. ${ }^{51-54}$ The $\mathrm{C}$-terminal tail domain consists of two long $\alpha$-helices important for filament assembly and cargo-binding. ${ }^{55}$ These functionally different parts of the molecule give a first hint toward functional

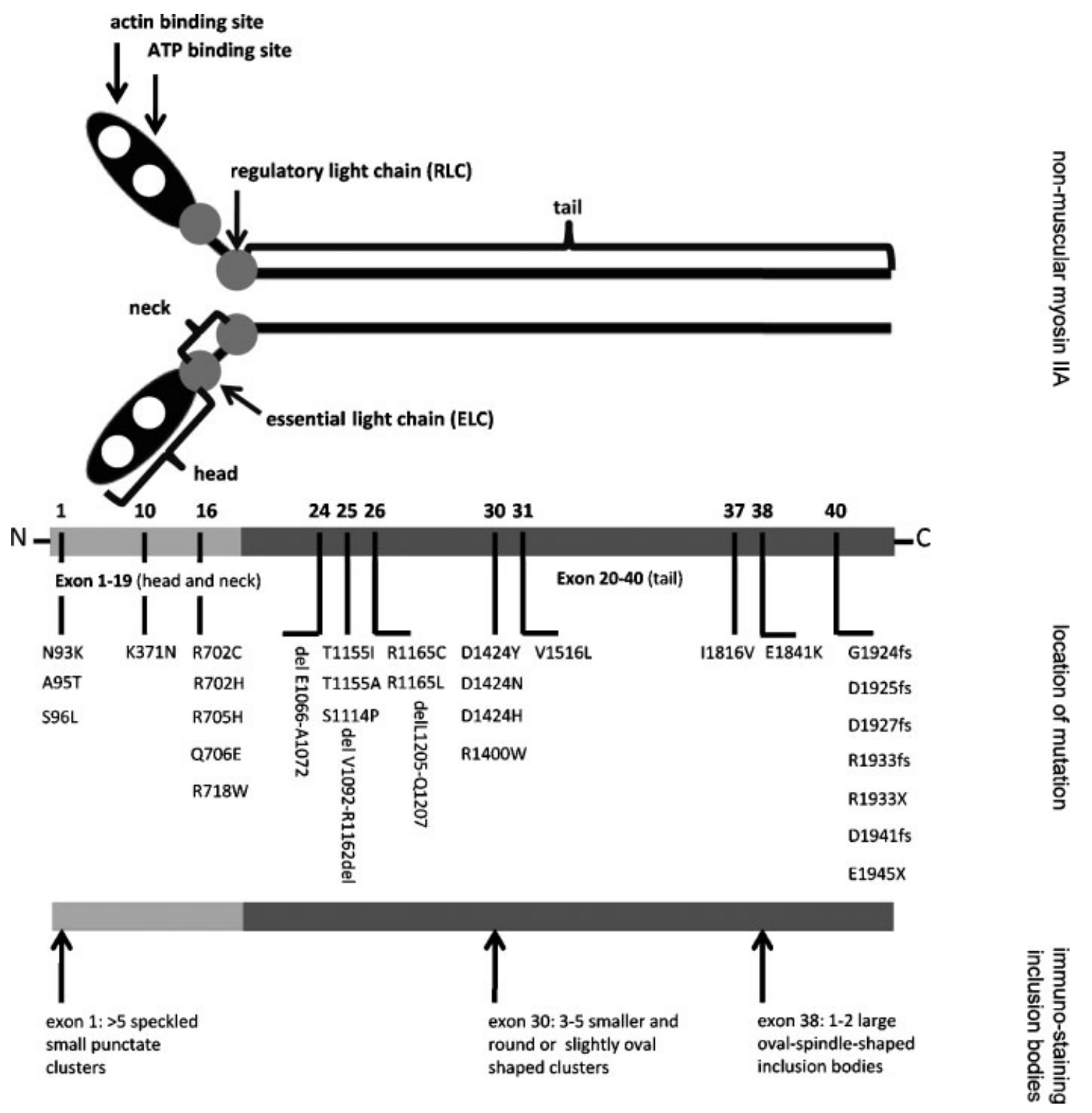

Figure 6 NMM-IIA structure and mapping of genetic mutations. The upper part of the figure shows a schematic representation of the NMM-Ila protein, which consists of two heavy chains and four light chains (gray dots). The heavy chains are structured into a head, a neck, and a tail. The light chains bind to the neck region. The middle part of the figure shows the MYH9 gene schematically with the regions coding for the head and the neck shown in gray and the region coding for the tail shown in black. The mutations reported in the literature are given at the respective parts of the gene. The lower part of the figure shows the location of the more frequent mutations and the morphologic characteristics of the inclusion bodies in the leukocytes, which are typically more than five small, speckle inclusion spots (mutation in exon 1), three to five small round to oval bodies (mutation exon 30), and one large spindle-shaped inclusion body (mutation in exon 38). 
consequences of mutations. Although mutations in the head region directly affect key functions of the motorprotein, mutations in the tail region appear to have less critical effects on function.

NMM-IIA is not restricted to hematopoietic cell lines, as studies of mouse embryos indicate that many tissues express this motoprotein. ${ }^{47,48}$ This makes the protein an interesting candidate in other nonhematologic disorders, and there is increasing evidence that MYH9 is also relevant in other nonsyndromic diseases (e.g., in nonsyndromic cleft lip and palate). ${ }^{56}$

\section{Heterozygote Mutation but Dominant Phenotype of MYH9 Disorders}

It has remained unresolved for a long time why a heterozygote genotype leads to a dominantly inherited phenotype for MYH9 disorders. Pecci et al ${ }^{57}$ used two different antibodies, one specific for a $\mathrm{C}$-terminal polypeptide sequence of the molecule and one specific for an $\mathrm{N}$ terminal globular head domain of the molecule, to solve this question. They observed a $50 \%$ reduction of functionally intact NMM-IIA expression in platelets, which confirmed the results of Deutsch et al. ${ }^{58}$ Using Western blot analyses of MYH9 leukocytes, they found, however, that the amount of free NMM-IIA in leukocytes was less than the $50 \%$ that would be expected in a heterozygote individual, and that the normal NNM-IIA molecules were complexed with the mutated forms within the clusters, hereby depleting the cell from functional NMM-IIA. Also, Kunishima et $\mathrm{al}^{22}$ found evidence for complex formation of wild-type and mutated NMM-IIa in leukocytes by immunofluorescence studies. In an in vitro model, Franke et $\mathrm{al}^{59}$ demonstrated assembly of wild-type and mutated myosin into bipolar filaments. Thus, in some cell lineages, the remaining $50 \%$ of functionally normal NNM-IIa in heterozygous MYH9 disorders is further depleted by "trapping" the unmutated protein into complexes with the mutated proteins.
Toren et $\mathrm{al}^{60}$ provided another explanation for the reduction of NMM-IIA in heterozygotes. They examined the potential role of another gene, fibulin-1, encoding an extracellular matrix protein, as a disease modifier. Eight unrelated families with autosomal dominant giantplatelet syndromes were studied for DNA sequence mutations and expression of the four fibulin- 1 splice variants (A to D). A mutation in the splice acceptor site of fibulin1 exon 19 was found in affected individuals of one Israeli FS family, whereas no MYH9 mutations were identified in this family. Unexpectedly, fibulin-1 variant D expression was also absent in affected individuals from all eight families, of whom seven had a MYH9 mutation as underlying cause. However, in all families, a putative antisense RNA to fibulin-1D was expressed. Transfection of the putative antisense RNA into H1299 cells abolished fibulin-1 variant $\mathrm{D}$ expression. Based on the observation that only affected individuals lack variant $\mathrm{D}$ expression and demonstrate antisense RNA overexpression, the authors suggested that some autosomal dominant giant-platelet syndromes are modified by aberrant antisense gene regulation of the fibulin-1 gene.

\section{The MYH9 Gene}

The MYH9-gene encoding NMMHC-IIA consists of 40 exons and is located on chromosome $22 \mathrm{q} 12-13 .{ }^{50} \mathrm{Up}$ to now, 31 mutations in 11 different exons have been described $^{4-6,20-30}$ (Fig. 6, Table 2). Exons 1, 10, and 16 encode the globular head and neck domain, and eight exons $^{24-26,30,31,37,38,40}$ encode the coiled coil domain. Most mutations in MYH9 disorders are missense mutations. In exon 40, both nonsense mutations and single-nucleotide deletions have been described. $^{24}$ Larger deletions are rare. ${ }^{25}$ Two small in-frame deletion mutations have been reported, ${ }^{6,24}$ as has one large inframe gene deletion in exon $24 .{ }^{20}$ Based on the Greifswald data, one of the most frequent mutations in the German population is located at position 1424 (Table 4).

Table 4 Mutations of the MYH9 Gene and Clinical Presentation of Thrombocytopenic Individuals Identified in Greifswald

\begin{tabular}{|c|c|c|c|c|c|c|}
\hline \multirow[b]{2}{*}{ Exon } & \multirow[b]{2}{*}{ Mutation } & \multirow{2}{*}{$\begin{array}{l}\text { Number } \\
\text { of Affected } \\
\text { Individuals }\end{array}$} & \multirow[b]{2}{*}{$\begin{array}{l}\text { Number of Individuals } \\
\text { with Thrombocytopenia }\end{array}$} & \multicolumn{3}{|c|}{$\begin{array}{l}\text { Number of Affected Individuals with Additional } \\
\text { Symptoms Beside Macrothrombocytopenia }\end{array}$} \\
\hline & & & & $\begin{array}{l}\text { Hearing } \\
\text { Impairment }\end{array}$ & $\begin{array}{l}\text { Renal } \\
\text { Impairment }\end{array}$ & Cataract \\
\hline 1 & S96L & 2 & 2 & 0 & 0 & 0 \\
\hline 10 & K371N & 2 & 2 & 0 & 0 & 1 \\
\hline 16 & R702C & 1 & 1 & 1 & 0 & 0 \\
\hline 16 & $\mathrm{R} 702 \mathrm{H}$ & 3 & 3 & 3 & 3 & 0 \\
\hline 25 & R1165C & 2 & 2 & 2 & 2 & 0 \\
\hline 30 & D1424N & 23 & 23 & 6 & 3 & 5 \\
\hline 30 & D1424H & 1 & 1 & 0 & 0 & 0 \\
\hline 38 & E1841K & 6 & 6 & 0 & 0 & 0 \\
\hline 40 & R1933X & 5 & 5 & 0 & 2 & 0 \\
\hline
\end{tabular}


To date, only heterozygote mutations have been identified in humans. Based on animal experiments, double heterozygote mutations or homozygote mutations of the MYH9 gene appear to be lethal. ${ }^{61}$

\section{ANIMAL MODELS OF MYH9 MUTATIONS}

In mice, the gene ortholog to the human MYH9 gene is localized on chromosome 15. Mouse NMMHC-IIA shows a $98 \%$ homology to human NMMHC-IIA. ${ }^{62}$ Knockout mice for the NMMHC-IIA gene show a loss of cell-cell adhesion, due to a decrease in E-cadherin and $\beta$-catenin expression in the cell membrane. These proteins were instead diffusely distributed within the cell plasma. These defects were reproduced by introducing small interfering RNA (siRNA) directed against NMMHC-IIA into wild-type embryonic stem cells. ${ }^{63}$ $\mathrm{MYH}^{-/-}$mice are not viable, ${ }^{62-65}$ whereas $\mathrm{MYH}^{+/-}$ mice were viable and fertile without gross anatomic, hematologic, or renal abnormalities. The heterozygous mice show normal distribution of NMM-IIA, and actin concentrations, but myosin concentrations are $\sim 50 \%$ of the concentrations in wild-type animals in all cell lines assessed (Pecci et $\mathrm{al}^{57}$ and Deutsch et $\mathrm{a}^{58}$ previously reported this reduction of NMMHC-IIA in platelets from patients with MYH9 disorders). Blood cell morphology and kidneys in the MYH $9^{+/-}$were normal, but interestingly, two of six mice exhibited hearing loss.

Léon et $\mathrm{al}^{33}$ generated mice with targeted knockout of the MYH9 gene in megakaryocytes. This platelet $\mathrm{MYH}^{-/-}$mice showed a strong increase in bleeding time and impaired thrombus growth and organization under flow conditions. Despite increased bleeding time, platelet aggregometry with any agonist remained nearly normal, although clot retraction was impaired.

Unexpectedly, NMM-IIA negatively regulates thrombopoiesis. MYH9 ${ }^{-/}$-deficient stem cells differentiate into megakaryocytes that are fully capable of proplatelet formation. When NMM-IIA was reintroduced into these cells, proplatelet formation was decreased. Thus, thrombocytopenia in MYH9 disorders results in ineffective platelet maturation due to the cytoskeletal abnormalities rather than from impaired megakaryopoiesis. ${ }^{66}$

\section{GENOTYPE-PHENOTYPE CORRELATION}

There is a controversial debate on whether a genotypephenotype correlation exists in MYH9 disorders (Table 2). A major problem for such an analysis is that many mutations reported were identified by highly specialized genetic laboratories that received DNA samples without having the chance to assess the clinical presentations of these individuals.

In vitro studies have shown that NMM-IIA binds to the membrane via $\mathrm{COOH}$-terminal regions with variable affinity and is therefore modulated by the tail domain, ${ }^{67,68}$ whereas the head region of the protein is important for the interactions with actin. According to different locations of the mutations in MYH9 disorders, variable phenotypes should be expected. There seems to be general agreement that individuals with mutations in exon 16 seem to have a higher risk for bleeding, renal impairment, and hearing impairment. Individuals with exon 16 mutations affecting amino acid 702 seem to be most affected (the Greifswald individual with this mutation is completely deaf). Individuals with this mutation also seem to have significantly larger platelets. ${ }^{69}$ This is plausible, as the R702C mutation has been shown by molecular modeling to result in conformational changes of the globular head of the protein, which results in impairment of the myosinATP-ase system (25\% MgATPase activity). ${ }^{7,70}$ It seems that other mutations in the head domain or close to the neck domain are also associated with a higher prevalence of other MYH9 syndromic manifestations. Mutations close to the neck could potentially impair actin-binding as mutations of $\mathrm{R} 702 \mathrm{C}$ and $\mathrm{R} 705 \mathrm{H}$ in cultured HEK293 cells showed a disturbed interaction of myosin and actin. ${ }^{71}$ Additionally, deletion mutants of N592 and C570 (generated to assess the effect of $\mathrm{N}$ - and C-terminal deletions) where transfected into HeLa and HEK293 cells alter cell shape, actin cytoskeleton, and cell adhesion properties. Interestingly, there is a mutation described in exon 16 of MYH9 at position R705, which causes hearing loss without thrombocytopenia. ${ }^{72,73}$ Individuals with mutations in exon 30 (especially at position 1424) seem to have a higher risk of developing cataracts and sensorineural hearing loss. ${ }^{23}$ For individuals diagnosed in our laboratory, both complications seem to appear at $\sim 40$ years of age or later indicating that compensatory mechanisms effective at younger age fail to compensate the NMM-IIa deficiency at older age.

Mutations in the tail region usually exhibit the mildest clinical phenotype. Although thrombocytopenia is present from birth, cataracts, hearing loss, and renal impairment occur only at older ages and are often subclinical. However, we identified one family with a mutation in exon 40 in whom the inclusion bodies were also small and very disorganized (as judged by ultrastructure) and in whom bleeding symptoms, renal impairment, and hearing loss were present. It might be that in these individuals, the tail function was more impaired, or an unknown modifier protein was additionally affected in this family. Table 4 summarizes data for the Greifswald individuals with MYH9 disorders, including their gene mutations and clinical presentations, which suggest a hierarchical order of mutation-phenotype correlates. Individuals with mutations in the head of the protein have a much higher risk for syndromic manifestations of MYH9 mutations than that of individuals with mutations in the 
tail region. Mutations in exon 30 seem to be at intermediate risk.

NMM-IIA is known to interact within the cytoskeletal protein network directly and indirectly with a large number of other proteins. ${ }^{74}$ Several of these interacting proteins are likely to modify the function of NMM-IIA and impact loss of function caused by reduced or dysfunctional NMM-IIA in individuals with MYH9 mutations. A greater understanding of the function of NMM-IIA and its binding partners is needed to better understand the different clinical presentations of patients with the same MYH9 mutation.

\section{THERAPY, MANAGEMENT, AND PROPHYLAXIS OF MYH9 DISORDERS}

\section{General Measures to Avoid Bleeding Complications}

As recommended for other bleeding disorders, medications that impair platelet function (e.g., aspirin) should be avoided in individuals with an MYH9 disorder. Regular dental care reduces the risk of gingival bleeding, and application of oily nose ointment can help reduce frequency of epistaxis. It is very important to prevent the development of iron-deficiency anemia, because a low hematocrit will exacerbate the impaired platelet-subendothelial interactions (impaired primary hemostasis). ${ }^{34,75}$

\section{Management of Menorrhagia}

There are no systematic studies on treatment of menorrhagia in women with MYH9 disorders. Based on our experience in Greifswald, hormonal modulation of the menses and antifibrinolytic agents at standard doses were effective, whereas DDAVP (deamino-8-D-arginine vasopressin; desmopressin [Minirin; Ferring GmbH, Kiel, Germany/CLS Behring, Marburg, Germany]) given as nose spray had little effect on menstrual blood loss in women with MYH9 disorders. This is consistent with the normal in vitro platelet function but impaired clot stability in the mouse model.

\section{Prevention of Renal Impairment}

In a randomized controlled trial of individuals suffering from nondiabetic renal disease, a combination of an angiotensin-II receptor blocker and an angiotensin-converting enzyme inhibitor showed effect in retarding progression of disease. ${ }^{76}$ In MYH9-related disease, pharmacologic blockade of the renin-angiotensin system reduced proteinuria in four individuals. ${ }^{77}$ It seems reasonable to start this treatment at the early stage of renal insufficiency in individuals with MYH9 disorders.

\section{Prevention of Hearing Impairment}

There is no effective primary treatment of hearing loss, although hearing aids and cochlear implants may be of benefit. However, as the inner ear cilia are fixed in their position by NMM-IIA, it is plausible that avoiding very loud noises at younger ages may postpone deterioration of ciliary function.

\section{Pregnancy and Childbirth}

Pregnancy and childbirth do not appear to be associated with a major increase in bleeding complications in individuals with MYH9 disorders. Furthermore, family histories suggest that these conditions may not put individuals at an increased risk for fetal or neonatal intracerebral hemorrhage. MYH9 macrothrombocytopenia by itself does not mandate caesarean section. However, in case of prolonged labor, caesarean section might be less traumatic than other obstetric interventions.

\section{Vaccination}

Individuals with MYH9 disorders should receive vaccination for pertussis (to avoid cough-induced hemorrhage) and measles (to avoid viral megakaryocytotoxicity).

\section{Surgical Interventions}

We have managed individuals with MYH9 disorders through a wide variety of surgical interventions, including dental extraction, tonsillectomy and adenectomy, cataract lens replacement, caesarean section, orthopedic joint replacement, cardiopulmonary bypass surgery, and neurosurgical interventions. None of the individuals showed severe hemorrhage, although dental surgery was associated with greater bleeding than usual. Our standard protocol is to give desmopressin (DDAVP) $0.3 \mu \mathrm{g} / \mathrm{kg}$ body weight before surgery and 24 hours later, and to combine this with tranexamic acid $0.5 \mathrm{~g}$ orally 3 times daily for 5 days after surgery (local application by mouth rinse after dental extraction). When the platelet counts of individuals with MYH9 disorders are monitored (e.g., before and during interventions), it is important to use always the same counting machine, as different machines show different error rates with giant platelets, and a large unexpected decrease in platelet counts may simply result from using another machine. Sehbai et $\mathrm{al}^{78}$ reported a neurosurgical intervention in a individual with MHA with administration of DDAVP without bleeding complications. Hip arthroplasty has also been performed in an individual with MYH9-related disorder without abnormal bleeding. ${ }^{79}$ 


\section{Thrombosis Prophylaxis after Surgery for MYH9 Disorders}

Although their platelet counts are decreased, individuals with MYH9 disorders are not protected from thrombosis. ${ }^{80}$ If DDAVP and antifibrinolytics are given, the risk for thrombosis might even be higher than that in the normal population, ${ }^{81}$ and thromboprophylaxis should be strongly considered in situations (e.g., postsurgery) with a high risk of thrombosis.

\begin{tabular}{|c|c|}
\hline \multicolumn{2}{|c|}{ ABBREVIATIONS } \\
\hline BSS & Bernard-Soulier syndrome \\
\hline DDAVP & deamino-8-D-arginine vasopressin \\
\hline EPS & Epstein syndrome \\
\hline FS & Fechtner syndrome \\
\hline GP & glycoprotein \\
\hline GPS & gray platelet syndrome \\
\hline $\operatorname{IgG}$ & immunoglobulin $\mathrm{G}$ \\
\hline ITP & (auto)immune thrombocytopenia \\
\hline MHA & May-Hegglin anomaly \\
\hline MLC & myosin light chain \\
\hline MPV & mean platelet volume \\
\hline MW & molecular weight \\
\hline MYH9 & myosin heavy chain 9 \\
\hline NMM-IIA & nonmuscle myosin IIA \\
\hline NMMHC-IIA & nonmuscle myosin heavy chain IIA \\
\hline P-LCR & platelet-large cell ratio \\
\hline SPS & Sebastian platelet syndrome \\
\hline
\end{tabular}

\section{REFERENCES}

1. Balduini CL, Cattaneo M, Fabris F, et al; Italian Gruppo di Studio delle Piastrine. Inherited thrombocytopenias: a proposed diagnostic algorithm from the Italian Gruppo di Studio delle Piastrine. Haematologica 2003;88:582-592

2. Toren A, Rozenfeld-Granot G, Rocca B, et al. Autosomaldominant giant platelet syndromes: a hint of the same genetic defect as in Fechtner syndrome owing to a similar genetic linkage to chromosome 22q11-13. Blood 2000;96:3447-3451

3. Martignetti JA, Heath KE, Harris J, et al. The gene for MayHegglin anomaly localizes to a $<1-\mathrm{Mb}$ region on chromosome 22q12.3-13.1. Am J Hum Genet 2000;66:1449-1454

4. Seri M, Cusano R, Gangarossa S, et al; The May-Heggllin/ Fechtner Syndrome Consortium. Mutations in MYH9 result in the May-Hegglin anomaly, and Fechtner and Sebastian syndromes. Nat Genet 2000;26:103-105

5. Kelley MJ, Jawien W, Lin A, et al. Autosomal dominant macrothrombocytopenia with leukocyte inclusions (MayHegglin anomaly) is linked to chromosome 22q12-13. Hum Genet 2000;106:557-564

6. Kunishima S, Kojima T, Matsushita T, et al. Mutations in the NMMHC-A gene cause autosomal dominant macrothrombocytopenia with leukocyte inclusions (May-Hegglin anomaly/Sebastian syndrome). Blood 2001;97:1147-1149

7. Heath KE, Campos-Barros A, Toren A, et al. Nonmuscle myosin heavy chain IIA mutations define a spectrum of autosomal dominant macrothrombocytopenias: May-Hegglin anomaly and Fechtner, Sebastian, Epstein, and Alport-like syndromes. Am J Hum Genet 2001;69:1033-1045

8. Noris P, Pecci A, Di Bari F, et al. Application of a diagnostic algorithm for inherited thrombocytopenias to 46 consecutive patients. Haematologica 2004;89:1219-1225

9. May R. Leukozyteneinschlüsse. Dtsch Arch Klin Med 1909; 96:1-6

10. Hegglin R. Gleichzeitige konstitutionelle Veränderungen an Neutrophilen und Thrombozyten. Helv Med Acta 1945;12: 439-440

11. Scholer VH, Schnös M. Observations on another carrier of the May-Hegglin anomaly of leukocytes and blood platelets. Schweiz Med Wochenschr 1960;29:1269-1273

12. Epstein CJ, Sahud MA, Piel CF, et al. Hereditary macrothrombocytopathia, nephritis and deafness. Am J Med 1972; 52:299-310

13. Peterson LC, Rao KV, Crosson JT, White JG. Fechtner syndrome- a variant of Alport's syndrome with leukocyte inclusions and macrothrombocytopenia. Blood 1985;65: 397-406

14. Greinacher A, Nieuwenhuis HK, White JG. Sebastian platelet syndrome: a new variant of hereditary macrothrombocytopenia with leukocyte inclusions. Blut 1990;61:282-288

15. Kunishima S, Kojima T, Tanaka T, et al. Mapping of a gene for May-Hegglin anomaly to chromosome 22q. Hum Genet 1999;105:379-383

16. Kelley MJ, Jawien W, Ortel TL, Korczak JF. Mutation of MYH9, encoding non-muscle myosin heavy chain A, in May-Hegglin anomaly. Nat Genet 2000;26:106-108

17. Balduini CL, Iolascon A, Savoia A. Inherited thrombocytopenias: from genes to therapy. Haematologica 2002;87:860880

18. Geddis AE, Kaushansky K. Inherited thrombocytopenias: toward a molecular understanding of disorders of platelet production. Curr Opin Pediatr 2004;16:15-22

19. Leung TF, Tsoi WC, Li CK, Chik KW, Shing MM, Yuen PM. A Chinese adolescent girl with Fechtner-like syndrome. Acta Paediatr 1998;87:705-707

20. Seri M, Pecci A, Di Bari F, et al. MYH9-related disease: May-Hegglin anomaly, Sebastian syndrome, Fechtner syndrome, and Epstein syndrome are not distinct entities but represent a variable expression of a single illness. Medicine (Baltimore) 2003;82:203-215

21. Kunishima S, Hamaguchi M, Saito H. Differential expression of wild-type and mutant NMMHC-IIA polypeptides in blood cells suggests cell-specific regulation mechanisms in MYH9 disorders. Blood 2008;111:3015-3023

22. Kunishima S, Matsushita T, Kojima T, et al. Immunofluorescence analysis of neutrophil nonmuscle myosin heavy chainA in MYH9 disorders: association of subcellular localization with MYH9 mutations. Lab Invest 2003;83:115-122

23. Pecci A, Panza E, Pujol-Moix N, et al. Position of nonmuscle myosin heavy chain IIA (NMMHC-IIA) mutations predicts the natural history of MYH9-related disease. Hum Mutat 2008;29:409-417

24. Kunishima S, Matsushita T, Kojima T, et al. Identification of six novel MYH9 mutations and genotype-phenotype relationships in autosomal dominant macrothrombocytopenia with leukocyte inclusions. J Hum Genet 2001;46:722-729

25. Kunishima S, Matsushita T, Hamaguchi M, Saito $H$. Identification and characterization of the first large deletion of the MYH9 gene associated with MYH9 disorders. Eur J Haematol 2008;80:540-544 
26. Arrondel C, Vodovar N, Knebelmann B, et al. Expression of the nonmuscle myosin heavy chain IIA in the human kidney and screening for MYH9 mutations in Epstein and Fechtner syndromes. J Am Soc Nephrol 2002;13:65-74

27. Ma ES, Wong CL, Shek TW, Hui SP. Hematologic and genetic characterization of an MYH9-related disorder in a Chinese family. Haematologica 2006;91:1002-1003

28. Dong F, Li S, Pujol-Moix N, et al. Genotype-phenotype correlation in MYH9-related thrombocytopenia. $\mathrm{Br} \mathrm{J}$ Haematol 2005;130:620-627

29. Lalwani AK, Goldstein JA, Kelley MJ, Luxford W, Castelein CM, Mhatre AN. Human nonsyndromic hereditary deafness DFNA17 is due to a mutation in nonmuscle myosin MYH9. Am J Hum Genet 2000;67:1121-1128

30. Otsubo K, Kanegane H, Nomura K, Ogawa J, Miyawaki T, Kunishima S. Identification of a novel MYH9 mutation in a patient with May-Hegglin anomaly. Pediatr Blood Cancer 2006;47:968-969

31. Canobbio I, Noris P, Pecci A, Balduini A, Balduini CL, Torti M. Altered cytoskeleton organization in platelets from patients with MYH9-related disease. J Thromb Haemost 2005;3:1026-1035

32. Paul BZ, Daniel JL, Kunapuli SP. Platelet shape change is mediated by both calcium-dependent and -independent signaling pathways. Role of p160 Rho-associated coiledcoil-containing protein kinase in platelet shape change. J Biol Chem 1999;274:28293-28300

33. Léon C, Eckly A, Hechler B, et al. Megakaryocyte-restricted MYH9 inactivation dramatically affects hemostasis while preserving platelet aggregation and secretion. Blood 2007; 110:3183-3191

34. Valeri CR, Khuri S, Ragno G. Nonsurgical bleeding diathesis in anemic thrombocytopenic patients: role of temperature, red blood cells, platelets, and plasma-clotting proteins. Transfusion 2007;47(4, Suppl):206S-248S

35. Kiefel V, Freitag E, Kroll H, Santoso S, Mueller-Eckhardt C. Platelet autoantibodies (IgG, IgM, IgA) against glycoproteins IIb/IIIa and Ib/IX in patients with thrombocytopenia. Ann Hematol 1996;72:280-285

36. Matzdorff AC, White JG, Malzahn K, Greinacher A. Perioperative management of a patient with Fechtner syndrome. Ann Hematol 2001;80:436-439

37. Bernard J, Soulier JP. Sur une nouvelle variété de dystrophie thrombocytaire-hemorragipare congénitale [in French]. Semin Hop 1948;24(Spec. No.):3217-3223

38. Pham A, Wang J. Bernard-Soulier syndrome: an inherited platelet disorder. Arch Pathol Lab Med 2007;131:1834-1836

39. De Marco L, Mazzucato M, Fabris F, et al. Variant BernardSoulier syndrome type bolzano. A congenital bleeding disorder due to a structural and functional abnormality of the platelet glycoprotein Ib-IX complex. J Clin Invest 1990; 86:25-31

40. Breton-Gorius J, Favier R, Guichard J, et al. A new congenital dysmegakaryopoietic thrombocytopenia (ParisTrousseau) associated with giant platelet alpha-granules and chromosome 11 deletion at 11q23. Blood 1995;85:18051814

41. Krishnamurti L, Neglia JP, Nagarajan R, et al. ParisTrousseau syndrome platelets in a child with Jacobsen's syndrome. Am J Hematol 2001;66:295-299

42. Freson K, Devriendt K, Matthijs G, et al. Platelet characteristics in patients with $\mathrm{X}$-linked macrothrombocytopenia because of novel GATA1 mutation. Blood 2001;98:85-92
43. Nichols KE, Crispino JD, Poncz M, et al. Familial dyserythropoietic anaemia and thrombocytopenia due to an inherited mutation in GATA1. Nat Genet 2000;24:266-270

44. Köhler M, Hellstern P, Morgenstern E, et al. Gray platelet syndrome: selective alpha-granule deficiency and thrombocytopenia due to increased platelet turnover. Blut 1985;50: 331-340

45. Nurden AT, Nurden P, Bermejo E, Combrié R, McVicar DW, Washington AV. Phenotypic heterogeneity in the gray platelet syndrome extends to the expression of TREM family member, TLT-1. Thromb Haemost 2008;100:45-51

46. Hodge T, Cope MJ. A myosin family tree. J Cell Sci 2000; 113(Pt 19):3353-3354

47. Maupin P, Phillips CL, Adelstein RS, Pollard TD. Differential localization of myosin-II isozymes in human cultured cells and blood cells. J Cell Sci 1994;107(Pt 11):3077-3090

48. Simons M, Wang M, McBride OW, et al. Human nonmuscle myosin heavy chains are encoded by two genes located on different chromosomes. Circ Res 1991;69:530539

49. Marigo V, Nigro A, Pecci A, et al. Correlation between the clinical phenotype of MYH9-related disease and tissue distribution of class II nonmuscle myosin heavy chains. Genomics 2004;83:1125-1133

50. Toothaker LE, Gonzalez DA, Tung N, et al. Cellular myosin heavy chain in human leukocytes: isolation of $5^{\prime} \mathrm{cDNA}$ clones, characterization of the protein, chromosomal localization, and upregulation during myeloid differentiation. Blood 1991;78:1826-1833

51. Kumar CC, Mohan SR, Zavodny PJ, Narula SK, Leibowitz PJ. Characterization and differential expression of human vascular smooth muscle myosin light chain 2 isoform in nonmuscle cells. Biochemistry 1989;28:4027-4035

52. Fox JEB, Phillips DR. Role of phosphorylation in mediating the association of myosin with the cytoskeletal structures of human platelets. J Biol Chem 1982;257:4120-4126

53. Suzuki Y, Yamamoto M, Wada H, et al. Agonist-induced regulation of myosin phosphatase activity in human platelets through activation of Rho-kinase. Blood 1999;93:34083417

54. Paul BZ, Daniel JL, Kunapuli SP. Platelet shape change is mediated by both calcium-dependent and -independent pathways. Role of p160 Rho-associated coiled-coil-containing protein kinase in platelet shape change. J Biol Chem 1999;274:28293-28300

55. Berg JS, Powell BC, Cheney RE. A millennial myosin census. Mol Biol Cell 2001;12:780-794

56. Chiquet BT, Hashmi SS, Henry R, et al. Genomic screening identifies novel linkages and provides evidence for a role of MYH9 in nonsyndromic cleft lip and palate. Eur J Hum Genet 2009;17:195-204

57. Pecci A, Canobbio I, Balduini A, et al. Pathogenetic mechanisms of hematological abnormalities of patients with MYH9 mutations. Hum Mol Genet 2005;14:3169-3178

58. Deutsch S, Rideau A, Bochaton-Piallat ML, et al. Asp1424Asn MYH9 mutation results in an unstable protein responsible for the phenotypes in May-Hegglin anomaly/ Fechtner syndrome. Blood 2003;102:529-534

59. Franke JD, Dong F, Rickoll WL, et al. Rod mutations associated with MYH9-related disorders disrupt nonmuscle myosin-IIA assembly. Blood 2005;105:161-169

60. Toren A, Rozenfeld-Granot G, Heath KE, et al. MYH9 spectrum of autosomal-dominant giant platelet syndromes: 
unexpected association with fibulin-1 variant-D inactivation. Am J Hematol 2003;74:254-262

61. Matsushita T, Hayashi H, Kunishima S, et al. Targeted disruption of mouse ortholog of the human MYH9 responsible for macrothrombocytopenia with different organ involvement: hematological, nephrological, and otological studies of heterozygous KO mice. Biochem Biophys Res Commun 2004;325: 1163-1171

62. D'Apolito M, Guarnieri V, Boncristiano M, Zelante L, Savoia A. Cloning of the murine non-muscle myosin heavy chain IIA gene ortholog of human MYH9 responsible for May-Hegglin, Sebastian, Fechtner, and Epstein syndromes. Gene 2002;286:215-222

63. Conti MA, Even-Ram S, Liu C, Yamada KM, Adelstein RS. Defects in cell adhesion and the visceral endoderm following ablation of nonmuscle myosin heavy chain II-A in mice. J Biol Chem 2004;279:41263-41266

64. Mhatre $\mathrm{AN}, \mathrm{Li} \mathrm{Y}$, Bhatia $\mathrm{N}$, et al. Generation and characterization of mice with MYH9 deficiency. Neuromolecular Med 2007;9:205-215

65. Parker LL, Gao J, Zuo J. Absence of hearing loss in a mouse model for DFNA17 and MYH9-related disease: the use of public gene-targeted ES cell resources. Brain Res 2006;1091: 235-242

66. Chen Z, Naveiras O, Balduini A, et al. The May-Hegglin anomaly gene MYH9 is a negative regulator of platelet biogenesis modulated by the Rho-ROCK pathway. Blood 2007;110:171-179

67. Murakami N, Singh SS, Chauhan VP, et al. Phospholipid binding, phosphorylation by protein kinase $\mathrm{C}$ and filament assembly of the $\mathrm{COOH}$ terminal heavy chain fragments of nonmuscle myosin II isoforms MIIA and MIIB. Biochemistry 1995;34:16046-16055

68. Murakami N, Elzinga M, Singh SS, Chauhan VP. Direct binding of myosin II to phospholipid vesicles via tail regions and phosphorylation of the heavy chains by protein kinase C. J Biol Chem 1994;269:16082-16090

69. Kunishima S, Yoshinari M, Nishio H, et al. Haematological characteristics of MYH9 disorders due to MYH9 R702 mutations. Eur J Haematol 2007;78:220-226

70. Hu A, Wang F, Sellers JR. Mutations in human nonmuscle myosin IIA found in patients with May-Hegglin anomaly and Fechtner syndrome result in impaired enzymatic function. J Biol Chem 2002;277:46512-46517

71. Li Y, Friedmann DR, Mhatre AN, Lalwani AK. MYH9siRNA and MYH9 mutant alleles: expression in cultured cell lines and their effects upon cell structure and function. Cell Motil Cytoskeleton 2008;65:393-405

72. Hildebrand MS, de Silva MG, Gardner RJ, et al. Cochlear implants for DFNA17 deafness. Laryngoscope 2006;116: 2211-2215

73. Lalwani AK, Goldstein JA, Kelley MJ, et al. Human nonsyndromic hereditary deafness DFNA17 is due to a mutation in nonmuscle myosin MYH9. Am J Hum Genet 2000;67:1121-1128

74. Cai Y, Biais N, Giannone G, et al. Nonmuscle myosin IIAdependent force inhibits cell spreading and drives F-actin flow. Biophys J 2006;91:3907-3920

75. Eugster M, Reinhart WH. The influence of the haematocrit on primary haemostasis in vitro. Thromb Haemost 2005;94: 1213-1218

76. Nakao N, Yoshimura A, Morita H, Takada M, Kayano T, Ideura T. Combination treatment of angiotensin-II receptor blocker and angiotensin-converting-enzyme inhibitor in nondiabetic renal disease (COOPERATE): a randomised controlled trial. Lancet 2003;361:117-124

77. Pecci A, Granata A, Fiore CE, Balduini CL. Reninangiotensin system blockade is effective in reducing proteinuria of patients with progressive nephropathy caused by MYH9 mutations (Fechtner-Epstein syndrome). Nephrol Dial Transplant 2008;23:2690-2692

78. Sehbai AS, Abraham J, Brown VK. Perioperative management of a patient with May-Hegglin anomaly requiring craniotomy. Am J Hematol 2005;79:303-308

79. McBane RD, Elliott MA, White JG, et al. Fechtner syndrome: physiologic analysis of macrothrombocytopenia. Blood Coagul Fibrinolysis 2000;11:243-247

80. Heller PG, Pecci A, Glembotsky AC, et al. Unexplained recurrent venous thrombosis in a patient with MYH9-related disease. Platelets 2006;17:274-275

81. Selleng K, Lubenow LE, Greinacher A, Warkentin TE. Perioperative management of MYH9 hereditary macrothrombocytopenia (Fechtner syndrome). Eur J Haematol 2007;79: 263-268 